\title{
NEGOTIATING CULTURAL IDENTITY THROUGH THE ARCHITECTURAL REPRESENTATION CASE STUDY: FOREIGN EMBASSY IN BELGRADE*
}

$U D C 725.125(497.11)=111$

\section{Dragana Vasiljević Tomić, Ana Nikezić\#, Dragana Ćirić}

\author{
University of Belgrade, Faculty of Architecture, Belgrade, Serbia \\ \#ana.nikezic@gmail.com
}

\begin{abstract}
This article reports methods and results of Master students' Diploma Thesis and Design research on representing identity through architecture. A group of 12 students have had the task to examine potentials and limitations of positioning and conceptualizing foreign Embassy in the context of Belgrade. Students were expected to rethink architectural representation and to find new possibilities for networking global aspects of identity and local aspects of context, thus creating architecture that emphasizes and promotes culture through its spatial and programmatic framework. Article concludes that architecture can become a resource for understanding cultural identity. It does not stop only at the physical, but affects the process of urban living, negotiating between global and local dimension of urban living, making a new culturally responsive urban landscape.
\end{abstract}

Key words: architecture, cultural identity, architectural representation, studio research method, students' work.

\section{INTRODUCTION: WHY EMBASSY?}

Current processes of European integration, and following local-culture's shrinkage within the common European political and economic entity, demands new ways of thinking about the city and the role of architecture. In response, the questions of cultural identities and local specificities are raised.

Mediating culture through spatial forms, typologies, practices and representations, architecture relates people and the city. Architecture is therefore given the possibility to become the cultural identity negotiator, and the ability to show itself as the cultural representative, signifier, and its agency. Within this assumption, we question particular spatial

\footnotetext{
Received May 13, 2013

* Acknowledgements: The article was written as a part of science research project - Spatial, energetic and social aspects of settlements' development and climate changes, TP 36035.
} 
typologies that support communication through architectural representation and practice, its role and position within the contemporary conditions of city-life.

The research case study is the Embassy in Belgrade, its transformation within the framework of the introduced concept and contemporary social, cultural and economic conditions. The embassy is identified as the appropriate research typology as the ongoing shift in embassy content, purpose and representation caused by new ideological, programmatic and social-cultural demands is recognized. It is expected to provide new forms of public embassy spaces involved in the process of negotiating between different local cultures within the supported global one, promoting cultural accessibility and communication between involved countries/cultures/societies, all with respect towards local values, continuity of urban ambience and identity, and established relation between people and the city, and within the contemporary free-time and everyday urban practices.

Following connection between local and global dimension of the city, public and private domain, external factors referring to urban surrounding, and internal ones regarding lifestyles, the Embassy design concept is directed to multi-level networking of defined characteristics. Those characteristics cover complex activity content, its flexibility and permeability, fusion of work and representation, integration in urban structure of the city and finally establishment of new cultural identity.

\section{THEORETICAL FRAMEWORK}

\subsection{Ideology, culture, architecture: cultural and architectural identities}

The link between architecture and ideology is situated in an attempt to identify the extent to which social values and practices can be negotiated through architectural space: its concept, materialization and representation. This conditionality is frequently established through ideological/historical work of the architectural object-as-artifact appropriation, where certain political/social/cultural identities are assigned to architecture on the basis of referent framework which provides and performs conditions for its realization. In other terms, certain ideology may be applied and structured within the architectural design process, resulting in equivalence between architectural and ideological elements, representing the process of translating certain value system into particular architectural terms.

The cultural issues are directed towards questions of identities, their construction, and their effects on the architectural representation - ethics and aesthetics of culturally questioned architectural identities. Cultural production implies mass-production of identities. Identity production works on the level of mediating messages, supproting ideologies, and their realization through the technological and financial contracts. From within the discourse of sociology, we can disscuss categories of identity construction, and investigate notions of individual/group role and personal identity (Stets et al, 2000).

In a broader sense, cultural identity is argued as being socially and ideologically constructed rather than belonging to some kind of independent, authentic or arbitrary culture (Koković, 2002), originated in some kind of given, unconditioned circumstances. Claims of spontaneity, intuitiveness, and occurrences, or preceding of ideological conceptualization, are also present in history and theory, even though belonging to some socio-cultural or ideological context. 


\subsection{Social-historical shifts and contemporary architectural condition}

Central point of this section is the extent to which social processes influence architectural production and practice. Present political and social context is influenced by global capital reconfiguration and capitalistic restructuring, and locally specified post-socialist transformation, along with the technological discourse which provides new forms, means and global strategies of capital circulation, advanced building techniques and production, restructuring at the same time everyday life and practices.

To explain this conditions and processes, following section presents a short review of significant socio-cultural and culture-historical factors as points of influence for the chosen research case study, defining its social context.

\subsection{1. 'Succession of modernity'}

David Harvey and Frederick Jameson argue that cultural condition of postmodernism represents continuity of a longer modernization process, initiated back in nineteenth century Western Europe. This "succession of modernity" (Soja, 2000), the most easily followed by Hobsbawm's chronology, is founded in the economic shift, restructuring crisis of the social, political and cultural relations; economic and cultural rhythms of capital; modernity, post-modernity, and short transitional periods between them.

1847. Britain and large part of Europe encountered economic crisis caused by capital over-accumulation, political and social changes. They marked the first transition in this historical succession. The changes were followed by consolidation of Industrial revolution in north-western cities and the economic expansion. Period after 1850's was centered around the international economic trade, rivalry between the countries, conflicts upon the territories out of the nation states, colonial reconfigurations, new nation-states figures, resulting in the new world map and new global geopolitical condition. New nation-states implied new modern societies and inner socio-political organization. Technological development in the following years, tracing it to the beginning of the $20^{\text {th }}$ century, produced new conditions of space and time govern-mentality, and new scientific and philosophical notions, experiences, and practices, conceptualized within the "time-space compression" ideology (Harvey, 1990). At that specific moment in history, these modernization processes (new means of communication and mechanical reproduction) were again marked with economic, cultural and political shifts resulting in new architectural forms.

This was the moment when representation was questioned within the arts field, along with its own disciplinary and institutional redefinition. That affected the field of architecture, as actual ideological position of that period advocated synthesis of all the arts, which suggested partly shared methods and knowledge. In comparison to arts whose production was not directly conditioned by economic processes, architecture was the most directly influenced by political and economic reality and production processes.

Therefore ongoing capitalist modernization, urbanization, industrialization and European integration processes of that period, conditioned importance of the relation between society and architecture, anticipating modernistic conceptions of architecture as a means of social transformation, or applied for social purposes. Modernism conceived the city (urban/architectural) spaces as spaces of social functions, while Postmodernism, as a reaction, tended to disengage space from its dependence on functions and to see it as autonomous formal system (Harvey, 1990). 


\subsubsection{Condition of postmodernity}

Postmodern advocacy of volatility and ephemerality of fashions and products, production techniques and labor processes, ideas and ideologies, values and established practices implies certain character in "thinking, feeling and doing" (Harvey, 1990: 285). Disposability concept further enabled rejection of values, lifestyles, stable relationships and of-attachment to things, places and people. In reverse, Harvey argues, these instabilities produced also the opposite need to maintain a certain kind of security, firm sense and continuity (resulting with historical and regional revival). Postmodernism thus implied profound intervention in human psychology - temporariness in the structure of both personal and public value system.

Volatility, represented as psychological/philosophical concept, is actually firmly derived from the broader economic transformation to flexible accumulation. These economic processes along with the development of the representation and identity market (as image became commodity in mass-production) caused shifts of capital towards the image production system. This 'image production industry" (Harvey, 1990: 290) becomes central for capital accumulation. Within the condition of postmodernity, increased production of signs and images, and the construction of new sign system and imagery, established culturally important positions and influences. From this perspective, Harvey represents culture as a "complex of signs and significations (including language) that mesh into codes of transmission of social values and meanings..."(Harvey, 1990: 299). Therefore stands the influence on the architectural discipline towards aesthetic appearances, signification, superficiality, and questions of representation in external matters, and flexibility and volatility considering internal program operations, experiential reception, often producing confusion and uncertainty.

After the 1968 events, Western stylistic postmodernism revived the concept of architecture-as-an-art. Architectural work was given the status of the cultural object with the ability to communicate. Artistic and architectural discipline and discourse defined the intersection and the common ground in their space/place representation and cultural signification through the specific use, introducing structuralistic tendencies and the questions of signification within the field of architecture.

The question of diminution of the spatial barriers is another postmodern critical issue. It can be analyzed on different levels. Harvey argues that money and commodities are primary barriers of cultural codes. Within the field of imaginary (invisible order) the question of barriers may refer to specific sense of seemingly accessible places, information, etc., produced by open sources ideology and services, enabled by the instruments of time/space compression (means of communication). Finally, in political and economical processes of boundaries reconfiguration, resulting with the new hierarchy of the localities, cities, regions and nation-states within the world system, the new global geography removed some legal and economic forms of territory division, covering them with the new economic organization and entities.

\subsubsection{Regionalisms, schools of architecture and tradition revival}

Crisis of socialist societies during 1980's and 1990's, the first wave of the post-socialist "blocked transition" (Vujović, 2005), represented as crisis of ideology not economy, were to a significant degree anticipated by the shift in cultural and social system 
values. Resulting ideological strategies created the shift in architectural discourse directing architectural design approach in: a) application of knowledge from the Arts History and History of Architecture, b) application of traditional architectural design principles, mediating between differing historical periods, c) search for the architectural references in local heritage and culture, d) the continuity of modernist tradition principles, based on the technological development and new technology and engineering principles, and f) application of philosophy directed principles in architecture. This contextual turn was influenced by state system crisis, cultural transformations and changes in industrial production, engaging different regionalisms, and reconsidering the question of architectural traditions.

In response to these issues, the research is structured around the question of dependency between global geopolitical and nation-state territory reconfigurations, the shift in ideological conceptions of the national/international and world countries economic and political relations, of culture which guided its imaginary discourse. Within the posited relation, the critical issue is how these ideologies influence the process of conceiving and theorizing the architectural boundaries, its agent the Embassy - program of engagement and negotiation. Concerning the embassy program within the concept of "mediating/negotiating culture" the aim is to define specific setting of cultural production objectives as a model for the new architectural requirements.

\section{WORKING METHOD}

The Master Diploma Course was organized for a group of 12 students. Classes were conducted twice a week in sessions six hours long, through joint discussions, site visiting, various analyses and numerous pin-up sessions, involving two phases: theory research defined through Master Thesis and spatial concept design research defined through Architectural Design.

The task was to situate and conceptualize the foreign Embassy in Belgrade. It meant investigating the embassy spatial and program possibilities relying on the identity of the chosen society, and examining the relationship between global/local culture and ways of its representation. Therefore, it was necessary to reconsider the position, scope, program, and its measure in the context of contemporary everyday life, and experience of architectural space. Students were expected to rethink architectural identity and to find new possibilities for networking global aspects of identity and local aspects of the context, thus creating architecture that emphasizes and promotes culture through spatial and programmatic framework.

Exploring the architectural and cultural program of the Embassy and the potential of its spatial interpretation, the research focused on two specific aspects: a) the shift of the embassy role in the city/program network and everyday life and b) the transformation of the spatial parameters of the embassy concept, content and context in terms of its architectural identity.

Therefore, various questions were opened:

- How to define the position of the Embassy in the context of the particular city and conditions of the contemporary urban life?

- In which way can Embassy become inclusive in an urban sense?

- How to define its borders and frames towards the city? 
- Which are the events and activities that the Embassy as a cultural institution can offer and complement to the city?

- What is the interpretative potential of architecture through the design process?

Theoretical texts collected for Master Thesis Reader were selected according to critical issues of architectural, social and ideological discursive points of influence that shape processes within the field of architecture.

As architectural authonomy was being criticized, and within the argument of impossibility of self-referentiality, postmodern architectural theorizing more often took forms of writtings by critics or specialists from other disciplines, advocating new ideology of architectural and urban space as socio-cultural medium. Interdisciplinary work enabled networking of different perspectives and methodological categories in defining architecture. The change of milenium as "an moment of reflection" (Vidler, 2000), marked numerous academic retrospectives, composed of writters from within and from outside of the architectural discipline.

According to these definitions texts in The Master Thesis Reader are taken as analytic tools rather then prescriptive positions. These reflections are then taken back to disciplinary elements, forms, spaces, technological and structural elements, and digital realm, with the aim of discovering the means of their representation and materialization, i.e. architectural interpretation of the analysed ideological positions.

Rethinking Architecture (Leach, 1997), Architecture and Identity: Responses to Cultural and Technological Change (Abel, 2000), and Architectural Theory since 1968 (Heyes, 2000), are chosen as reviews of this architecture-ideology/identity relation in history. Archaeology of Knowledge (Foucault, 1998) is proposed as philosophical work that argues this layering of historical shifts and of ideas in history, suggesting the concept of archive as their form, and the methodological apparatus for discoursive work - the theoretical framework structure under the concpet of discourse.

Current ideological directions are given through the writtings Nomadology or Ideology? Zizek's Critique of Deleuze (Sinnerbrink, 2006), Tolerance as an Ideological Category (Zizek, 2008), Non-places: Introduction to an Anthropology of Supermodernity (Auge, 2005), Postmetropolis (Soja, 2000), and The Condition of Postmodernity (Harvey, 1990). They represent broader ideological framework for thinking identities and critical concepts within, through and for the embassy program.

Questions of identity are examined through the identity theory and social identity theory. Here we can extract categories of the identity construction form and strategy, and investigate notions of individual, group/role and person identity (Stets and Burke, 2000).

Semiotic perspective and the questions of signification and mediation of architectural space through architectural representation and practice/operational reception, can be networked through Harvey's reflections on social conditions of representational turn, Function and Sign: Semiotic of Architecture (Eco, 2009), providing insights in semiotic methodology structural framework considering architecture as an entity/object/sign engaged in the pocesses of signification and messages mediation, and Anaesthetic of Architecture (Leach, 1999) presenting contemporary investigation in this field, discussing processes and forms of aesthetization, and anaesthetization comprehended as "traded substance for appearance, depth for surface, aesthetic for the image" (Leach, 1999), with the critique of postmodern monumentality, consumerism, spectacle, and advertising culture. 
Defined objectives and values, suggested through the reader, were mediated through methodological guidance of the design process. Typology transformations, questions of boundaries formation (exclusion), or specific demands of public spaces inclusion and integration in contemporary urban social, cultural and economic politics of city-space and everyday urban life, were framing invisible quality within the space accessibility questioning the design process. Architectural intervention, nor its scale or architectural identity was not known at this stage, just the critical position and specific space values. Problems of the spatial concept setting were resolved through the architectural design.

Directing architectural and cultural references, students structured architecture according to their Master Thesis research investigation. Values, conclusions, individual design objectives, or specific research topic defined in Master Thesis, represent basic input data for design research. The task is their design activation: translation, interpretation, or agency and critic through spatial and architectural terms and elements.

Architectural identities and their historical development, or moments of their definition within the architectural discourse and discipline, become more relevant at this point of design process, living aside social and political conditions analysed more comprehensively in the thesis research. They serve as objects of comparison and direct, weather affirmative or critical, references in defining the shift or continuity in architectural identity and spatial application in contemporary moment, referring to research in design. The cultural identities and values recognized as significant, indirectly guided elements of architectural program, its condition and representation.

In reveresed architecture-ideology relation, architectural design and architectural analyses of defined program, its inner logic and external political position, can serve as a device for present society problem detecting and deeper analyses or rationalizations, ideologies and objectives - exetrnal conditions reasearch by design. These conclusions are established upon the design project completion.

Through thesis research and design research students become aware of the categories which define identity/ideology and architectural space construction, and methodologies which make their interdisciplinary dialog possible. Therefore approaching discipline of architecture with the broader knowledge, critical stance and data-based design action.

Depending on the design method and approach, within the master thesis framework, defined embassy program and spatial/social/cultural objectives, the work with students was organized towards specific individualy guided design solutions, discussed within group sessions, where tested and exposed to different points of view, questions, and interpretations.

\section{CASE Study: ForeIGN EMBASSY IN BELGRADE}

The critical review of both parts of Master Project, the thesis and the design complets this course "Design by Research", acquiring certain position by critical statement in response to argued and applied values, principles and identities. The final students' work with consistent individual design method represent and illustrate this academic shift, its arguments towards scientific and analytical thinking through design process, integrated in teaching methodology. For the case study, two students' research that represent and perform consequently these design research principles were selected. 


\section{1. Space Governmentality - Microgeopolitics of Architectural Space: Demolishing the Fortress: (Re) Interpretation of the Architectural Concept of the American Embassy in Belgrade, Ivan Filipović}

The research starts from the socio-political theory and accurate ideological and technological positions which dominate and structure the discourse of the chosen country. Speaking of the military conception of history (Virilio: 1977, 1986, 2000) it puts the accent on military, political and technological rather then economy transformation. It investigates their historical context with an emphasis on the present condition in relation to spatial and architectural conditions which represent and advocate them.

The main subject is built landcape within the conception of protected and fortified space, "the islands of enclosure and anticipated protection against real and imagined dangers of daily life" (Soja, 2000), regarding the shift in mode of environment regulation from "hard edges of enforcement and enclosure to the softer manipulations of ideology and the reshaping of urban imaginary" (Soja, 2000).

The design researches concepts of closed fortress-like spaces, sofisticated control and surveillance, discussing replacement of the polis with police, and new constructions of urban-architectural imaginary through new technological devices and implosion of simulation conceptions and practices as more subtle forms of spatial and social regulation (Soja, 2000: 299). Identified destruction of public space, and the architectonics of security-defined urbanism, refering to Davis "security-obsessed urbanism", representing "microgeopolitics of state power", bring in the question of the architectural policing of social boundaries (Soja, 2000: 300) within new intercultural politics of space and place significantly different from rigidly polarized historical positions and discourses.

The main dialog is lead between identity design and control through corresponding spatial strategies and concrete architectural settings, and through strategies of imaginary/ identitiy and boundary control by invisible cultural, political and psycho-social conceptions, and their virtual and visual interpretations by new technologies (Figure 1).

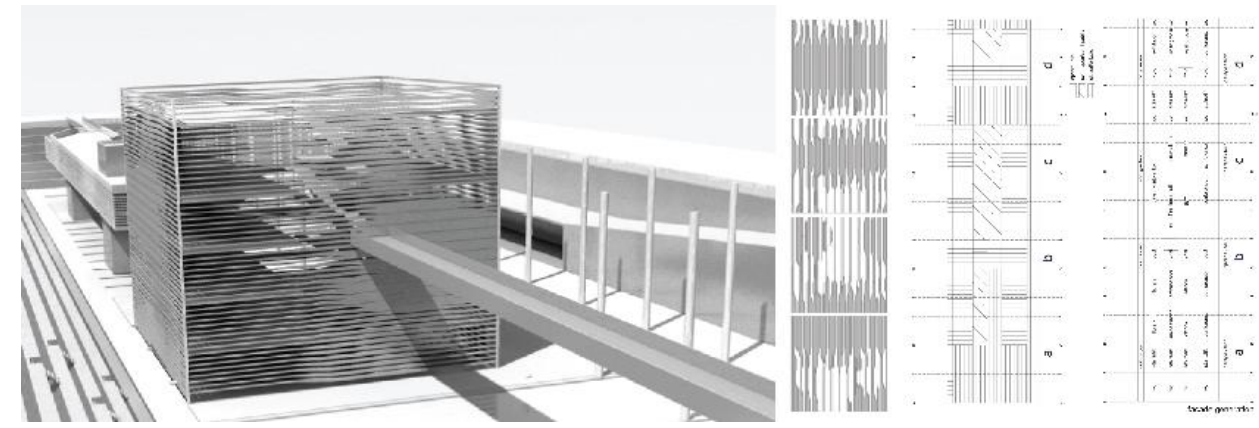

Fig. 1 American Embassy in Belgrade, Ivan Filipović

The hypothesis that virtual control and imaginary boundaries could completely replace traditional concepts of spatial control (e.g. conceptions of space incarceration and urban fortresses) was at the end denied. From the attempt to recreate destructed public space in citizens' favor, final architectural setting confirmed fortress status realized within 
contemporary conditions presented in the study. Distinctive, formal articulation, and visual manipulation enabled by material performances and final treatment, represent architectural statement towards external public realm, the cut and the mask as the boundary, and restricted accessibility, while the inner operational logic is strictly controled and defined for different user's groups through architectural structure, avoiding any kind of intertwinning, rejecting the concept of the embassy as a mediating center.

\section{2. Anthropological, architectural and security issues: Non-places in Embassies, Spanish embassy in Belgrade, Aleksandra Ginić}

Research starts from the socio-anthropological issues considering spatial references with the central theoretical study Non-places: Introduction to an Anthropology of Supermodernity (Mark Auge, 2005), non-place referring to places that do not hold enough significance to be regarded as places which notes the cultural shift, supermodernity. This cross-analysis brings in comparative method of anthropological and architecural disciplinary interpretations of spatial conditions, putting the accent on humanistic aspects of living and constructed environment. It takes into consideration everydayness and everyday practices, performative and operational movement models and logics, reflecting them on the philosophical and psycho-sociological positions in relation to spatialpragrammatic examples.

Questions of experience, behaviour, emotion, or sense in/of place (anthropological place vs non-place, anonimity and identity) indicates and confirms (architectural/urban) space as sentient being, derived from Harvey's definition of "the city as body politic and sentient being" in contrast to "the city as static, reduced, esthetic object" (Harvey, 2003) or mere representation and information. The latter referes also to historical direction, or demand, towards structuralism and semiology that suggested architecture with the aim of conveying, or mediating identities, messages and significations (Eco, 2009).

This provided architectural space with the new level of signification. In further historical development and theoretical/practical transformation, these demands were integrated into design process, which resulted in new programmatic and performance schemes of architectural settings, and new process logics.

Other phenomenological issue of this study is the question of secrecy (as an ideological construction) and concrete security measures that produce these psychological and spatial boundaries of certain exclusion/inclusion, examining the position of the architectural design/plan within these objectives. The context of this new security environment research is placed between globalization and national identity (Cha, 2000).

Space-Movement-Event scenarios (Tschumi, 2008) serve as guiding principles for further research method. They direct the research towards a diagrammatic work, considering diagram as a tool of spatial scripting, or movement notation, that records spatial experience, event, performance (Tschumi, 2008). Thus creating spatial discourse that connects time, action and movement, investigates perceptive and performative aspects of architectural space, and their relation.

Scenario follows three groups of users, or three different levels of security/protection, making them the main constitutive element of the architectural design. Use of grafic and simulation devices, and analysis of the given security procedures (of space and people 
flow control), led to conclusion that dissolved the critic of non-places with the neccesity and demands of international security policy and laws (Figure 2).

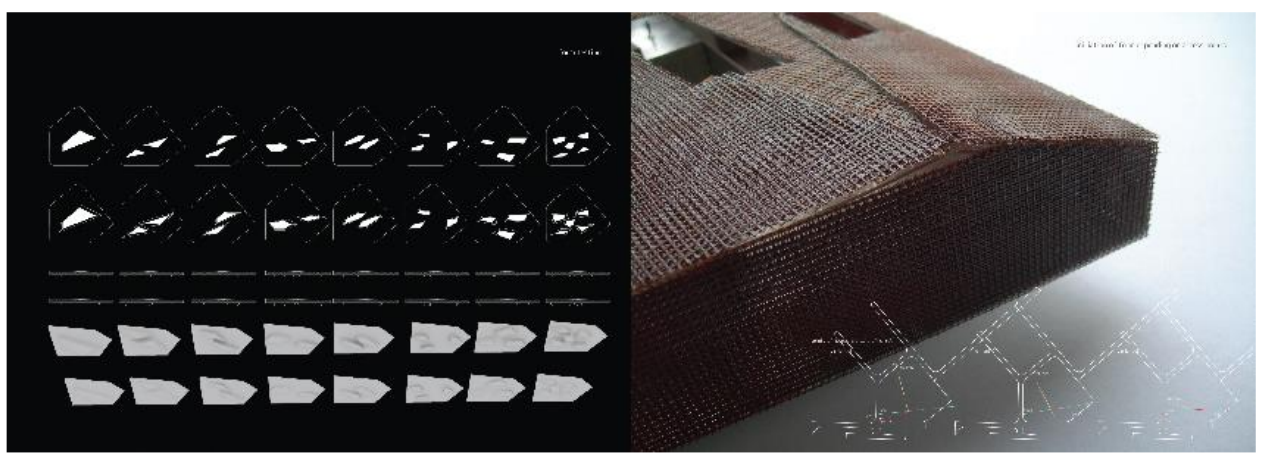

Fig. 2 Spanish embassy in Belgrade, Aleksandra Ginić

As a final statement, in response to research results, architectural design maintained the objective of findings, according to which specificity and place (public realms of the embassy intended for the public use, communication and representation), in comparison to non-place (strictly programmatic definition of embassy service spaces) keeps the distinctiveness and protection of the inner functional core in formal, operational, program and esthetic architectural and urban statement. The design obtained specific architectural identity of the embassy typology in relation to national values and identities, representation and ideology of a chosen country, and of international policy and legislations considering the countries in question.

\section{CONCLUSION}

Concepts of political and cultural field of the region, private and public sphere of contemporary everyday urban life, created a comprehensive network for the embassy investigation. The theme demanded thinking in terms of distinctiveness of the regional culture and architecture within the current process of globalization, trying to determine specific relation between international and national, specificities of the context and its particular demands, and their representation and advocacy in different contexts, a well as the levels of universality that enable transitions: a cross-cultural/architectural/economic/ political processes, which the embassy spatial and program concept stands for.

Theory and design research method and work within the Master program consequently led students' projects from the theory and interdisciplinary research introduction, theoretical conclusions and objectives, chosen subject, basic concepts of spatial and programmatic conditions and their evaluation, through the elements of the architectural space, its structure, materialization, and atmosphere, towards integral design projects, complete in their quality.

Through the research, students acquired knowledge in critical and analytical thinking, developing a stronger theoretical basis for their understanding of the architectural field. They questioned the embassy role in the city-program network and contemporary urban 
everyday life considering the embassy's cultural and mediating function in relation to publicity. Through positioning within the national/international relation, regional/global context, students consider the inner programmatic definition, and question identity construction within cultural representation. Mediating possibilities of embassy's architectural space, its borders and frames, students also tested its inclusiveness and exclusiveness through design program and spatial parameters.

Research and design approach advocated that architecture doesn't have to become an instrument of mere functionality, putting the accent on its mediating task of establishing specific relation between the embassy service, administration and government demand for the closure, but also to satisfy the environmental and human oriented aspects of openness and accessibility, maintaining our physical, psychological, biological, aesthetic, and intellectual comfort in the inherited urban (public) space, human in proportions and urban in everyday experiences.

Design approach within the embassy studio task introduced new thinking and better architecture, supporting the quality of the environment which it drew references from, and was created for - a living landscape, and concluded that context and regional culture, with their historical spatial continuity and structure/environment relation, can acquire their specific identity and contemporary social and urban integrity only through spatial definition and mediation of an architectural concept as the key element.

\section{REFERENCES}

1. D. Koković, "Integration processes, regionalism and keeping of cultural identity", u Sociološki pregled, Vol. 36, No. 1-2, 2002, pp. 163-171.

2. E. Stets, J. and Peter J. Burke, "Identity Theory and Social Identity Theory", in Social Psychology Quarterly, Vol. 63, No. 3, 2000, pp. 224-237.

3. E. Soja, Postmetropolis. Critical studies of cities and regions, Oxford: Blackwell Publishers, 2000.

4. D. Harvey, The Condition of Postmodernity, An Enquiry into the Origins of Cultural Change, Cambridge Mass. and Oxford: Blackwell Publishing, 1990.

5. S. Vujović, "About Yugoslavian Urban Sociology", in Urban Sociology, S. Vujović and M. Petrović, Eds. Belgrade: Zavod za udžbenike i nastavna sredstva, 2005.

6. N. Leach, Ed., Rethinking Architecture: A Reader in Cultural Theory, London: Routledge, 1997.

7. C. Abel, Architecture and Identity: Responses to Cultural and Technological Change, Oxford: Architectural Press, 2000.

8. M. Heyes, Ed, Architecture Theory since 1968, London, Cambridge, Mass.: The MIT Press, 2000.

9. M. Foucoult, Archaeology of Knowledge, Translation Kozomara, M, Belgrade: Plato and Novi Sad: Izdavačka knjižarnica Zorana Stojanovića, 1997.

10. R. Sinnerbrink, " Nomadology or Ideology? Zizek's Critique of Deleuze"., in Parrhesia Journal, No.1, 2006, pp. 62-87. http://www.parrhesiajournal.org/parrhesia01/parrhesia01_sinnerbrink.pdf

11. S. Zizek, "Tolerance as an Ideological Category", in Critical Inquiry, No. 34, 2008, pp. 660-682.

12. M. Auge, Non-places: Introduction to an Anthropology of Supermodernity, (Augé, M. Non-lieux: Introduction à une anthropologie de la supermodernité, Seuil, 1992), Translation Jovanovic, A, Belgrade: Biblioteka XX vek, 2005.

13. U. Eco, "Function and Sign: Semiotic of Architecture", Translation T. Kosić and S. Stamatović, in V. Đokić and P. Bojanić, Eds, Theory of Architecture and Urbanism, Belgrade: Faculty of Architecture, Belgrade University, 2009, pp. 155-173.

14. N. Leach, Anaesthetics of Architecture, Cambridge, Mass.: MIT Press, 1995.

15. D. Harvey, Paris The Capital of Modernity, New York and London: Routledge, 2003.

16. V. Cha, "Globalization and the Study of International Security", in Journal of Peace Research, Vol. 37, No. 3, 2000, pp. 391-403. 


\section{ČITANJE KULTURNOG IDENTITETA KROZ ARHITEKTURU STUDIJA SLUČAJA: AMBASADA U BEOGRADU}

Ovaj članak se, kroz metode i rezultate rada u okviru Master diplomskog projekta na Arhitektonskom fakultetu Univerziteta u Beogradu, bavi istraživanjem kulturnog identiteta kroz arhitekturu. Grupa od 12 studenata imala je zadatak da ispita potencijale i ograničenja pozicioniranja i konceptualizacije jedne, konkretne, ambasade u prostornom i društvenom kontekstu Beograda. Od studenata se očekivalo da preispitaju mogućnosti prezentacije kroz arhitektonski jezik $i$ da pronađu nove mogućnosti za umrežavanje globalnim aspektima identiteta i lokalni aspekti konteksta, stvarajući arhitekturu koja ističe $i$ promoviše kulturu kroz prostorni i programski okvir. Članak zaključuje da arhitektura može postati izvor za razumevanje kulturnog identiteta. Ona se ne zaustavlja samo na fizičkoj strukturi, beć utiče na proces urbanog života, balansirajući između globalne i lokalne dimenzije urbanog života, oblikujući novi kulturni pejzaž grada.

Ključne reči: arhitektura, kulturni identitet, arhitektonska reprezentacija, metod istraživanja, studentski radovi 